\title{
"Expressive line" in the history of German and Russian graphics: From past to present
}

\author{
I. S. Golikova \\ St. Petersburg Stieglitz State Academy of Art and Design, \\ 13, Solyanoy per., St. Petersburg, 191028, Russian Federation
}

For citation: Golikova I. S. "Expressive line" in the history of German and Russian graphics: From past to present. Vestnik SPbSU. Arts, 2018, vol. 8, issue 1, pp. 52-63.

https://doi.org/ 10.21638/11701/spbu15.2018.104

In the present article, prompted by Anselm Kiefer's exhibition in The Hermitage Museum, parallel trends in German and Russian $20^{\text {th }}$ century graphics are analyzed. The role of German Expressionism in the history of graphic art is clarified. The author managed a comparative analysis of the works of German and Russian artists of the 1910s and 1920s, who worked with printed graphics. Excerpts from the articles of the leading Russian art critics of that period are cited, confirming the importance of comprehension of the concept of "graphics" (grafika) for Russian art theory. The role of Anselm Kiefer in the European art of the last quarter of the $20^{\text {th }}$ century is viewed from the point of his conceptualization of artistic techniques and, in particular, the connection in his works of painting and printed graphics. The final conclusions of the article are connected with the rationale for further research into the phenomenon of the "parallel relationship" between Russian and German graphics.

Keywords: graphics, Russian art, German art, $20^{\text {th }}$ century art, Anselm Kiefer.

The recent exhibition of Anselm Kiefer (May to September 2017) in The Hermitage Museum once again updated the question of the relationship between German and Russian art. This question has a rather long history reflected, for example, in the book of Dmitry Sarabyanov "Russian painting of the XIX ${ }^{\text {th }}$ century among European schools: the experience of comparative research" (1980) [1]. This problem has remained relevant in the twentieth century, which, for example, found its place in the famous book by Igor Golomstock "Totalitarian Art" (1994) [2], as well as in exposition projects, among which the most significant were exhibitions "Moscow - Berlin. 1900-1950" and "Moscow Berlin / Berlin - Moscow. 1950-2000", held, respectively, in 1996 and 2004. At the same time, the analysis of similar trends in the German and Russian graphics of the twentieth century has not yet been sufficiently developed. Therefore, the "experience of comparative study" that we propose in this article can to some extent be considered one of the first steps towards a comprehensive analysis of the phenomenon of "parallel interaction" between German and Russian artistic cultures.

Perhaps the first to draw attention to this phenomenon was the famous Russian art critic Jacov Tugendhold, who wrote an article in 1926 on an exhibition of German art in Moscow. In this text there are, in particular, such words:

"There was a time when (not to mention the era of Overbeck and Alexander Ivanov), when Russian painting echoed with the German one (such is, for example, the influence of

(c) Санкт-Петербургский государственный университет, 2018 
the Düsseldorf genre painters on some of our Peredvizhniki), when Russian artists studied in Germany, moreover, when reproductions from the German Symbolists, Böcklin and Stuck, were extremely popular with us" [3, p. 130].

With respect to graphics, it is worth noting that the problem of comparative characteristics of the German and Russian graphic "school" was raised in the well-known book of Yuri Gerchuk "History of graphics and Art of the Book" (2000), where examples of Russian graphics from the 1910s are viewed in one context (although without direct comparison) with the experiments of German expressionists in print techniques [4, p. 275].

Truly revolutionary changes in the history of graphic art appeared with German expressionism. Particularly important is the work of artists who were part of the well-known group "The Bridge" (Die Brücke). Ernst Ludwig Kirchner, Max Pechstein, Karl SchmidtRottluff and other participants of this vivid association of the early $20^{\text {th }}$ century contrasted the relatively calm and harmonious art of the previous period with a wild, spontaneous, extremely tense style that they demonstrated in both painting and graphics. While their pictorial experiments as a whole can be included in the general trend of European Expressionism, the graphics of Kirchner and his adherents are a genuine phenomenon. The old German tradition found its reflection in these engravings, dating back to Gothic times, with its characteristic expressive forms. Also, the participants of Die Brücke creatively interpreted the artistic discoveries of post-impressionism in the graphics, primarily the images of Paul Gauguin, whose works played a significant role in the history of expressionism.

It is important to note that during their close association from 1905 to 1913 they made prints independently, without the participation of professional printing masters, which corresponded to their principles of direct work with artistic material in painting, sculpture and graphics. Similar qualities were characteristic of their older adherent, Emil Nolde, one of the first "new graphic artists" of the $20^{\text {th }}$ century. Also, one can not but note the artistic originality of the graphic works of the outstanding German sculptor Ernst Barlach, his lithography and woodcuts in which the angular-simplistic laconicism of the Gothic Old German engraving is exacerbated by the characteristic expressionistic "struggle with the material", becoming dramatic, saturated with psychological tension.

German expressionists embodied the spirit of freedom in sharp, contrasting, extremely emotional images of black and white graphics, the idea of artistic protest - against the academic tradition, against the conventions of bourgeois society. Die Brücke artists sought spontaneously and directly, to imbue vital force in their art, and in the images, almost devoid of plot, in landscapes and compositions with nude figures (Fig. 1). Printed graphics were necessary for German expressionists and for popularization of their ideas, engravings duplicated in this sense the role of exhibitions, and also brought some revenue. It's amazing that Die Brücke artists, with their free way of life and strong originality in art, were very practical in their own way. In an effort to talk about their goals, promote their work and make a living, they devoted a lot of time and effort to assembling exhibitions that traveled around Germany and attracting collectors and like-minded people.

Graphic experiences of participants of another German expressionist group - "The Blue Rider" (Der Blaue Reiter) possessed similar qualities, among its members, in terms of addressing the contrasting graphic style of the black and white image; Franz Mark is the first one to stand out (Fig. 2).

Sometimes engravings of the expressionists used color, although its application is to be considered more of an experimental technique that did not receive serious develop- 


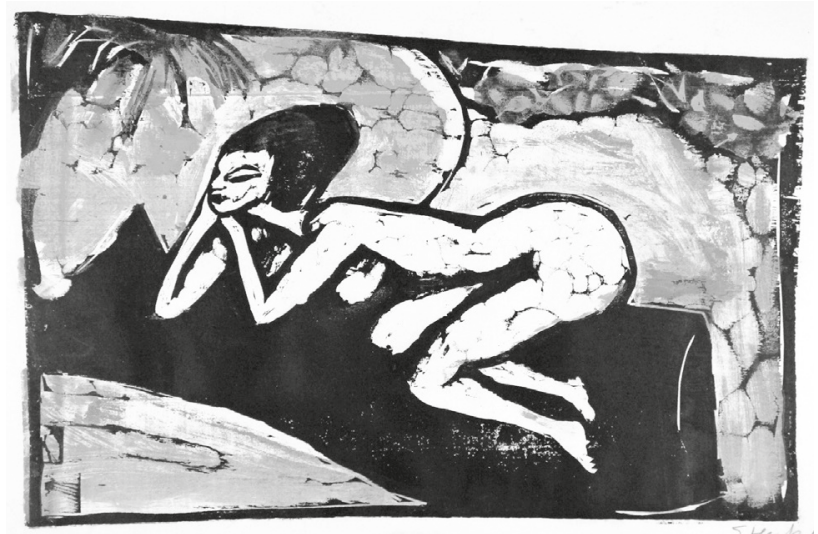

Fig. 1. Erich Heckel. Lying on a Black Cloth. 1911

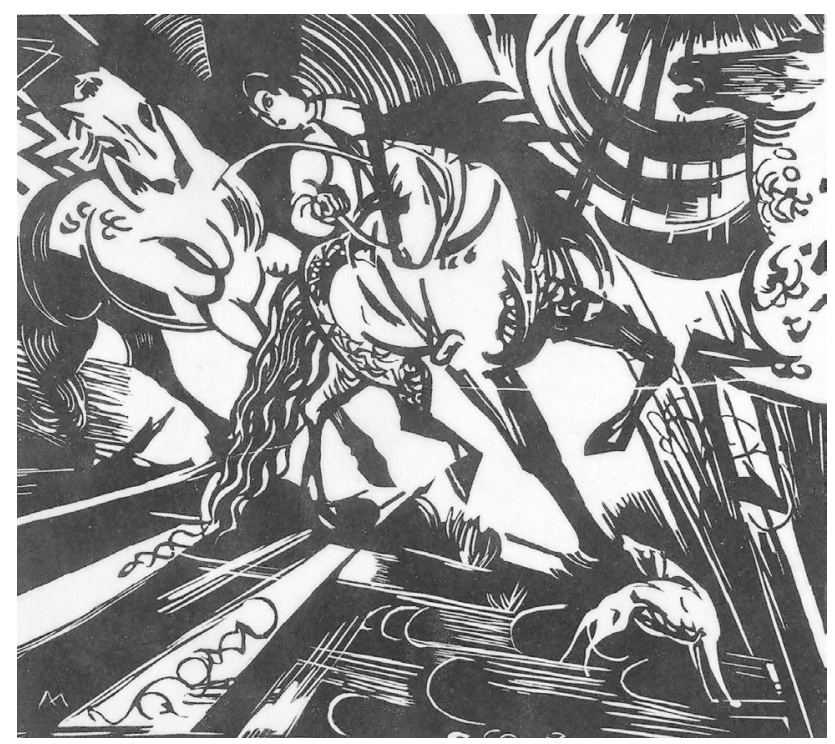

Fig. 2. Franz Marc. The Riding School. 1913

ment in the future. And as for the deep black color in combination with the neutral "white" paper surface, this unusually expressive contrast has become something fundamental to the graphic style of the $20^{\text {th }}$ century. Thanks to the style and manner of everyday scenes expressionists' scenes - turned into a gloomy or feverishly joyous phantasmagoria, where expression is sort of detached from the narrative and the image.

Wood engraving grew to become the most characteristic graphic technique for expressionists, although they created equally impressive works in etching and lithography. Perhaps they were attracted to xylography (woodcut) by its complexity, rigidity and need for almost sculptural work with wood. Expressionists, in the words of Yuri Gerchuk, "are at war with the wood, they shred and tear it". Their "angular, rough strokes, on white planes, as if accidentally left, the remnants of the black surface, not completely cut off, are a clear demonstration of the very process of fighting the board, cutting out from it a schematic, decidedly simplified image ... wrenching from the tree its own emotional gesture" [4, p.272]. 
In the Expressionist graphics there was also a stylization when they interpreted the techniques of the early German woodcuts of the 15th century, or the images of African "tribal art". As for parallels with the German Gothic tradition, they are evident in a series of woodcuts by Ernst Barlach of 1919-1922, where an original image of medieval religious art is realized (Fig. 3).

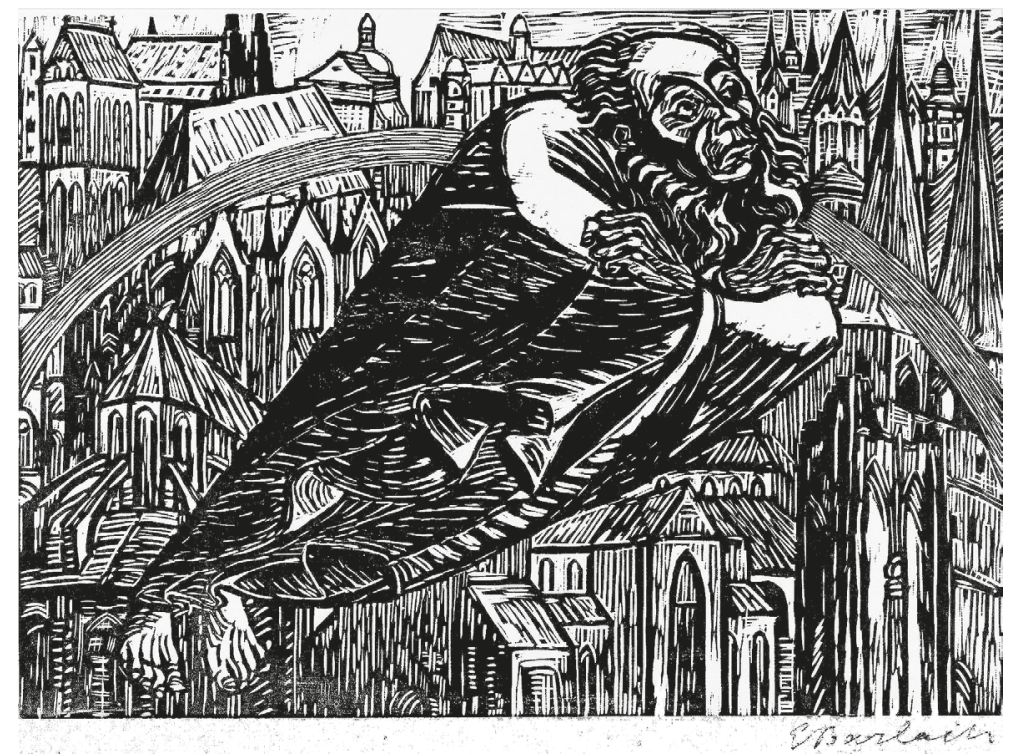

Fig. 3. Ernst Barlach. The Cathedrals, from "The Transformations of God". $1920-1922$

In response to the First World War, German artists continued the tradition of printed cycles depicting the war and its consequences (historically the best-known example is "The Disasters of War" by Francisco Goya). Thus, indelible impressions leave disturbing images in a series of etchings of Otto Dix called "War" (1924), created under the influence of his own military experience (Fig. 4). The shocking, sharp graphic of expressionism became an instrument of agitational and satirical graphics during the years of the First World, whose singular representative was Georg Gross, with his grotesque, socially pointed images, perceiving the surrounding reality as pathology, a disease. Another bright representative of the following (after the participants of Die Brücke and Der Blaue Reiter groups) was the generation of German expressionists, whose military experience played a significant role in his artistic formation, was Max Beckmann.

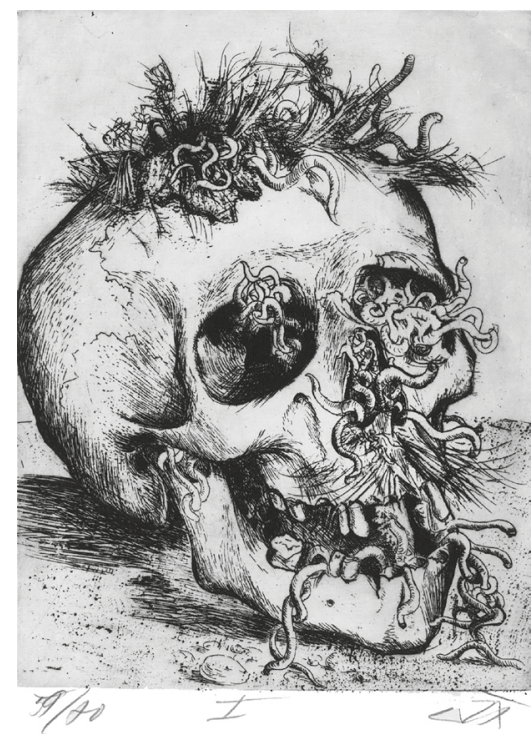

Fig. 4. Otto Dix. The Skull, from “The War". 1924 
His relatively rare graphic works, in comparison with Dix and Gross, speak about the atmosphere of apathy and disappointment that gripped Germany in the 1920s, and also reflect the general mood of the artistic movement known as the "New Objectivity" (Neue Sachlichkeit).

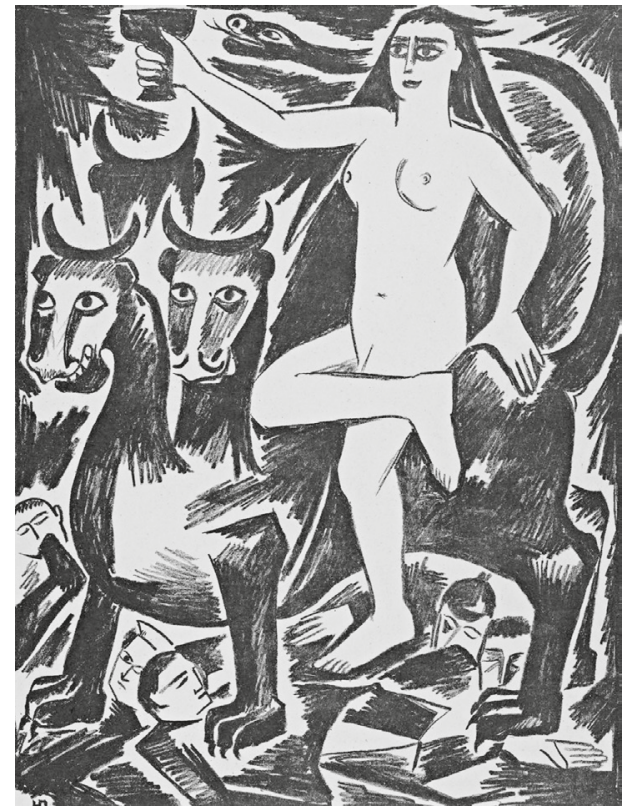

Fig. 5. Natalia Goncharova. The Virgin on the Beast, from "Mystical Images of War". 1914

It is interesting that in Russia, for which participation in the First World War had truly catastrophic consequences, the artistic interpretation of this event can hardly be described in the same terms as in the works of the German Expressionists. A characteristic work in this context is the famous album of lithographs by Natalia Goncharova "Mystical images of war" (1914) with it's majestic personifications of the coming apocalypse (Fig. 5). There is something in common with German expressionistic graphics, first of all a hard black and white contrast, intentional primitivization, but still the differences are more important. The features of these differences are related to the fundamental features of German and Russian art. In one case, color and line directly interact with the sensual, expressive consciousness, in the other - the "expressive line" is compensated by the plot component, a kind of story in the basis of the work.

The origins of modern Russian graphics in their practical and theoretical dimensions are addressed to a situation centuries old, to the time of unusual intensity and talent. Graphic culture experienced an extraordinary rise at that time, and it is obvious that it was then that a peculiar tradition of book and easel graphics was born in Russia, which was then transformed into a new full-blooded development in the 1920s and 1930s. From 1900 to 1920, art criticism in the person of its representatives such as Nikolai Radlov, Yakov Tugendhold and Abram Efros laid the foundations of the theory of graphics as a special kind of art characterized by the allocation of specific visual qualities - the line, tonal contrast, silhouette, flatness.

A peculiar result of the rapid growth of graphic culture, as well as the outcome of the arguments of domestic artists and art theorists on the properties of graphics as a special kind of art was the article by Yakov Tugendhold, the greatest art critic of the first two decades of the century. His "Engraving and Graphics" (1927) relates:

"The new graphics first of all revived the engraving and - most importantly - the forgotten, having such a glorious past engraving on the tree. [...] The transition from pure graphics to "engravings" is one of the main features of the new Moscow graphic school" [5, p. 249].

In one of the issues of the magazine "Apollo" for 1913 there was a review by Nikolai Radlov "About the exhibition of drawings and prints", which appeared in connection with a retrospective. The author postulates: 
"It is time for us to understand that graphics is different from the art of painting, not only in terms of its means, but also in its goals, that the area is no less valuable, no less wide, but independent and detached from painting" [6, p. 53].

Radlov writes about the sources of modern graphics, highlighting, in particular, the Japanese engraving and creativity of Aubrey Beardsley, and also compares Russian graphics (mentioning the masters of the "World of Art" with their foreign counterparts). And, it should be noted, this comparison is clearly in favor of domestic artists:

"Germans honor the traditions of Schongauer and Durer; their art is conservative.

We Russians do not know such drawings.

Our graphics almost entirely grew on the cult of the graphic form and through it found or still searching for its content" [6, p. 54].

In the article dedicated to the outstanding artist Vladimir Favorsky, who did a lot for the revival of xylograph techniques, Abram Efros wrote:

"In the current days, Russian art has areas that can be called heroic. Such areas are our graphic arts in general, and Russian wooden engraving in particular. <...> The only area where we are equal to the West, where we compete with it, is Russian graphics with its brilliant general culture, with great individual talents, and the only point where we stand above European art, where we transcend it and legislate it, our engraving is on the tree. It is now at the zenith of her heroic band" [7, p.37].

In 1923 The History of Engraving and Lithography in Russia by Erich Hollerbach was published. This book presents a unique historical document - the text of the report of an outstanding artist, master of etching Vasily Mate "Engraving and its independent meaning", read in 1912 at the All-Russian Congress of Artists. We quote a fragment of it:

"The main difference between engraving and photography is that the photographer reproduces accurately and reproduces unusually quickly, and the engraver is inaccurate; but this inaccuracy creates a wonderful world, general world, each engraver translates into his language, transmits different shades and makes you admire the new hidden wealth of artists. [...] Engraving has its own language, a combination of strokes, light and shade, creating a captivating charm that has nothing to do with either color or patterned paintings. [...] The last half of the century was a time of decline for engraving, in the sense of its wide distribution, but the time comes when the photographic reproduction becomes more and more banal - unleavened. Society begins to be burdened with photography: understands all its insignificance, and it is clear - inevitably interest to engraving should be revived. Interest in engraving should be revived every year. More and more engravers are appearing in Europe. The invasion of machine production in the field of arts has been condemned for a long time, and only amicable efforts of society and time are needed to get rid of the monotonous ligature of art - photos" [8, p. 11].

One can not but note the relevance of these words, which show that from an objective standpoint over the last hundred years, little has changed in the situation of interaction by the form of art and the relation of traditional art to "new technologies". Vasily Mate was an enthusiast of printed graphics, and this is the reason why he spoke only about engraving, as if implying that it is a graphic art that is a special kind of art that can be countered "coloring and drawing of the picture". He did not use the term "graphics" in his speech, but affirming the qualities of engraving as a counterbalance to painting and, especially, actual photography, speaks of the self-determination of the kind of art that after a while would be called graphics. 


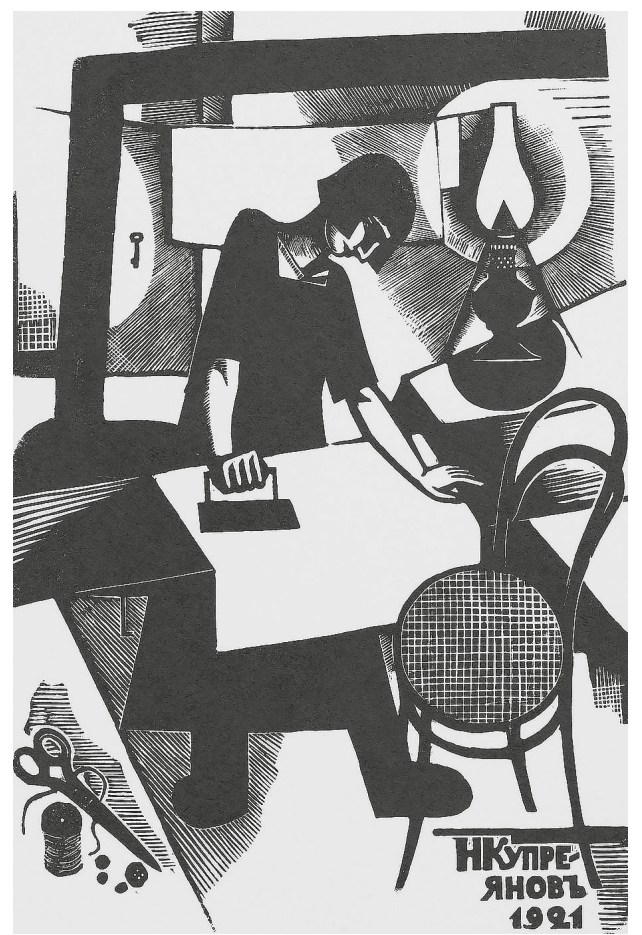

Fig. 6. Nikolai Kupreyanov. Woman Ironing (Natalia Sergeevna Iznar). 1921
In Russian art of the 1910s and 20s, expressionistic tendencies were expressed rather brightly, though they did not take shape in a holistic direction. So expressive techniques are clearly marked in the works of such outstanding representatives of Russian graphics of this period as Nikolai Kupreyanov and Alexei Kravchenko. Like the German expressionists, simple subjects, portraits, landscapes, images of animals, are infused with gloomy romance and drama. But the plastic engraving of Kupreyanov is stricter, there are no tattered, unorganized strokes (Fig. 6). And as for Kravchenko, his expressive images are organized with an enchanting compositional device reminiscent of the baroque style (Fig. 7).

In addition to Kupreyanov and Kravchenko, the images of some engravings by Andrey Goncharov, a disciple of Favorsky, can also be considered expressionistic. In particular it is worth mentioning his portraiture, namely "Self-Portrait" and "Portrait of an Old Woman" (Fig. 8). But, again, at all similar moments, bringing together Russian graphics from 1915 to 1920 with earlier works

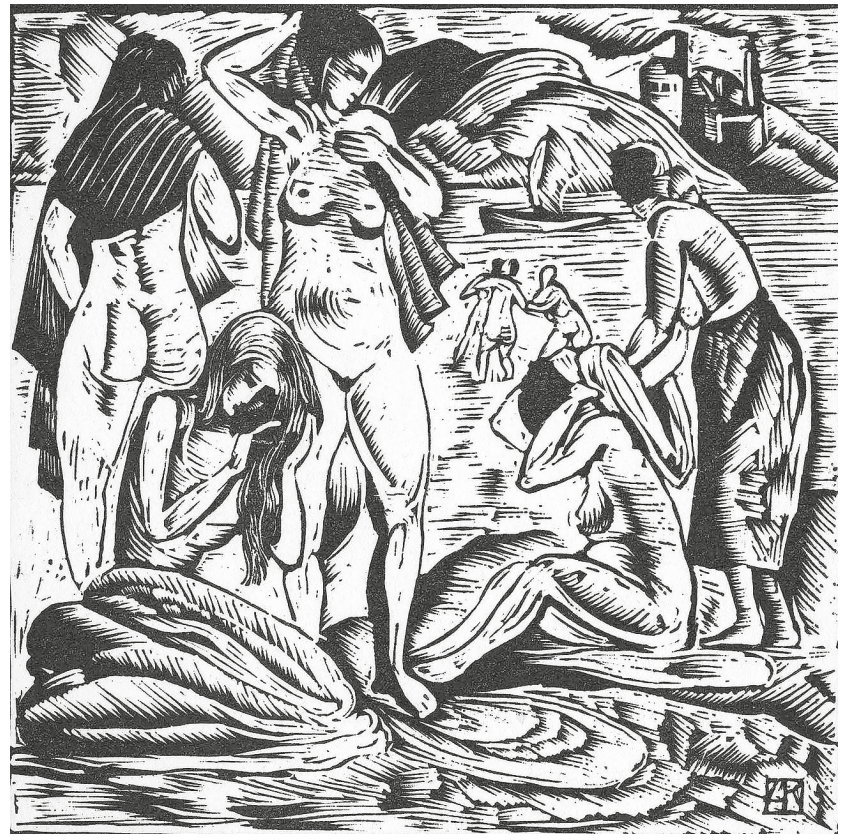

Fig. 7. Alexei Kravchenko. Bathing. 1919 
of German expressionists, it is obvious that here fundamental differences should also be taken into account. These are expressive images, but this is not Expressionism.

The Russian artist is more interested in compositional organization of the image, he pays more attention to what in the traditional "coordinate system" would be justified as an artistic device, artistic quality. Thus, it can be concluded that the differences between the German and Russian "new engraving" are connected both with the features of the form, and with the conceptual moments. In terms of the form, this is the desire for experiment, which is ordered by traditional structural qualities. Concerning the concept - it is the preservation of attention to the narrative, the subject matter of the work. This is particularly evident in figurative images, where figures

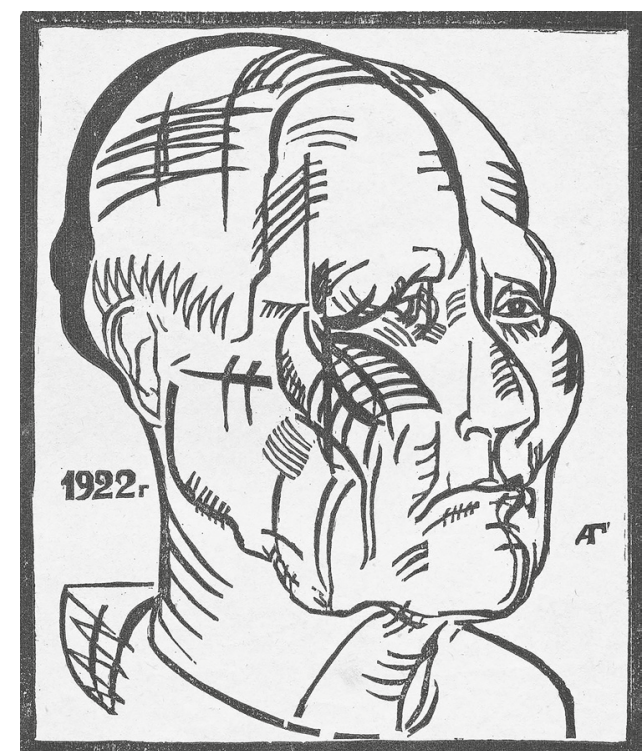

Fig. 8. Andrey Goncharov. Portrait of an Old Woman. 1922 are understood in principle in the same way as they were in the art of the $19^{\text {th }}$ century.

In this connection, it can be noted that Russian art has a certain special feeling associated with the notion of realism. Perhaps it is so, as is confirmed by recent practice, when in Russia attention to the ideology of realistic art raises again. However, reasons may be sought elsewhere and have to do with the features of understanding form. When comparing, it can be concluded that examples of Russian graphics of this time are characterized by a greater rigor of form, in them the contrast of black and white is understood precisely in a specific graphic sense. While their German Expressionist colleagues resolve the dualism of black and white in a more picturesque fashion. What does this mean? There are few quite interesting things, like the fact that it was not accidental in Russia that the concept of "graphics" took shape as a separate art form.

In the twentieth century, there was a somewhat strange situation, when in Russia (The USSR) graphics gradually began to be perceived as a kind of art, without regard as to whether the work by technique was a drawing or a printed work having circulation. In the West, graphics is more like a set of printed techniques, which, among other things, still makes it difficult to translate the terms "graphics" (grafika in Russian) and "graphic artist" (khudozhnik-graphik in Russian) from Russian to any European language. Despite the fact that originally grafika was a foreign word, in the Russian language it acquired a specific autonomy. This situation is reminiscent to the term "design", that is, also in the context of Russian language and Russian culture has a greater degree of autonomy than in the context of European linguistic traditions.

In Russian-language art tradition, by the mid- $20^{\text {th }}$ century, the term grafika had already been formed into a scientific category associated with the classification of art forms. This is evident from the way Boris Vipper writes about graphics in his classic work Introduction to the Historical Study of Art: 
In the characteristic of fine arts, we turn first and foremost to graphics. This name has been established, although it unites two completely different creative processes and although various other names have been proposed: among others, for example, "the art of the lead" (M. Klinger) or "paper sheet art" (A. A.Sidorov) [9, p. 15].

Later on, he writes about the features of graphics from the position of its categorical specification: "However, it should be remembered that the term "graphics" covers two groups of works of art, united by the general principle of aesthetic conflict between the plane and space, of which we spoke above, but which at the same time are completely different in origin, in technical process and by designation, drawing and printed graphics. [...] One should not think that printed graphics are always a drawing, engraved on a tree or on metal; no, it is a specific composition, specially conceived in a certain technique, in a certain material and is unrealizable in other techniques and materials. And each material, each technique is characterized by a special structure of the image" [9, p.17].

Also, we quote another passage from the article by Jacob Tugendhold:

The turbulent era of the Revolution found its sharp and clear form in graphics, the laconic and dynamic language that was needed and that could not be given by painting, which in the first post-Revolutionary years was experiencing a severe crisis. Is it not the explanation for the rise in drawing over ten years as an independent branch of art that allowed the Tretyakov Gallery to open several new rooms dedicated to "pure drawing" [5, p.249].

Tugendhold not only points to the wide significance of graphics as an art form (where the form, image and technique are interrelated, and where the quality of "graphicality" becomes fundamental), but also leads to the ideological basis for its development in Soviet Russia. Thus, the approval of graphics in our country in the category of a separate art form has a rather complex basis, wher factors of art, history and even ideology are interrelated.

As for ideological moments, it is worth noting that they played a role in the new increase of attention to graphics in the art of the postmodern period. This is precisely the context that relates to the work of Anselm Kiefer, and to activities of contemporary Russian artists, for whom graphics are a relevant technology.

In this regard of Russian artists, it is worth highlighting two representatives of St. Petersburg art: Petr Beliy and Petr Shvetsov. They are active representatives of the newest art scene, and what they do, one way or another, fits into the concept of "conceptual installation". In the 2000s, they gained some notoriety due to their large-scale, even huge, engravings in which they used conservative graphic techniques in combination with new printing technologies. As a result, their exhibition projects as it were broadcasted by means of "total graphics" vague conceptual content, which turned out to be quite successful.

Kiefer, whose style is reminiscent of the works of Beliy and Shvetsov, is an older artist, he is one of those who ascended the art scene in the 1970s, at the time when the problem of technology was acute enough in the world of Western art. (At this time, art in Soviet Union thought in other categories, and artists Beliy and Shvetsov had only just appeared in the world.) In the 1980s Kiefer became one of the most famous painters in the world, and his paintings sometimes represented a certain combination of painting, engraving and installation. For example, he pasted huge prints on boards, poured acrylic paint over them with, and atop it all mounted a bulky object such as a piece of wood. This had its own meaning, which, as in the case of German expressionists and their Russian contemporaries, should be analyzed in a comparative analysis framework. 
In the second half of the $20^{\text {th }}$ century, after the Second World War and subsequent cultural cataclysms connected in many ways with the growing influence of American mass culture, the usual system of genres, previously based on the choice of this or that subject matter disintegrated. Artists strangely focused on the problems of artistic language (discourse), its methodology, as if they had suddenly turned into scientists, reflecting on some fundamental questions. In this situation, the notion of art forms has become "oldfashioned", especially since a new paradigm of artistic expression has emerged - installation, a kind of synthesis, where art forms and artistic techniques equal the ordinary object of reality, the ordinary object.

As for graphics, the impact of the pop-art was significant here, in the context of which the attention was once again paid to printed materials and collages. In the 1960s, German artists Sigmar Polke and Gerhard Richter worked in an ironic pop style known as "Capitalist realism". Their work as a whole differed from brightly optimistic, colorful products of American and British pop artists and reflected their ambivalence towards consumer culture. Polke and Richter were strangely attracted to the effect that has given poor quality to photos from newspapers and magazines of the time. Artists intensified this effect when reprinting, using silk screen printing technology, photolithography (offset printing) and other methods of reproduction that allowed them to display their protest against the attitude to art as an expensive commodity.

By the end of 1970s, after a growing interest in lithography and silk screen printing, attention was once again paid to wood engraving, which was largely due to the movement of Neo-Expressionism. In relation to other representatives of this movement in Germany - George Baselitz, Jürg Immendorff and A. R. Penck - Anselm Kiefer stands aside. He seems to be too carried away by the possibilities of the material, and also he strives to embody in his works a kind philosophical meaning that is not typical to expressionism or its continuation in the work of neo-expressionists - the German "New Wild Ones" (Neuen Wilden).

Kiefer experimented with printed images, so that they became something unique in the context of his picture-installations, and, on the contrary, created so many series of paintings that they in quantitative terms became something like a series of engravings. He re-used the printed blocks to create additional effects in new works, in general, treated creativity unusually technically for a modern artist.

In 1969 Kiefer began to study with Joseph Beuys at the Kunstakademie Düsseldorf, where, under Beuys' influence, he began to study the "heritage problem" of the German past. In the future, Kiefer continued to work in this direction, gradually increasingly complicating the individual interpretation of German history and historical mythology through the complication of artistic technique.

As a characteristic example of his peculiar graphics, you can cite the work "Grane", stored in the Museum of Modern Art in New York (1980-1993). The name is associated with the mythical horse Grani. The author thus hints at the famous opera cycle of Richard Wagner, the tragic fate of his protagonists Siegfried and Brunhild. This heroic horse is a recurring motif in the Kiefer's work. In the version stored in the Museum of Modern Art, the horse is enveloped in a funeral pyre, which is connected with the culmination of the opera. The border in the interpretation of Kiefer is like a skeleton, and in general this composition is filled with a sense of tragedy. Moreover, it is important that this feeling is also achieved by engraving technique; by the way Kiefer uses it, this rough "sharp cut" on wood. 
As follows from the commentary typical for the whole of Kiefer's work, the artist here explored the "identity" of his country, the moral and philosophical problems that were facing Germany after World War II [10, p.308]. His image hints at the German historical and cultural past, but also serves as a metaphor for universal suffering, sacrifice and destruction. The monumental scale of this work required the joining together of thirteen sheets of paper on which a print of an engraving was printed.

As for Russian art, among its representatives there is hardly a figure close to Kiefer in the depth of his tragic perception of history. At the same time, some contemporary Russian artists (including the two above mentioned) are in many ways analogous to him in the scale of "project thinking", when their graphic works are combined into a single whole like a total installation. It is also impossible not to recall that some leading representatives of "Moscow Conceptualism" - for example Ilya Kabakov and Viktor Pivovarov — have long been engaged in book graphics, which could not but affect their conceptual thinking. These, and other examples, show that the topic of comparative characteristics of German and Russian art is worthy of further study, as well as practical display in future exhibition projects.

\section{References}

1. Sarab'ianov D. V. Russkaia zhivopis' XIX veka sredi evropeiskikh shkol: opyt sravnitel'nogo issledovaniia [Russian painting of the XIX century among European schools: the experience of comparative research]. Moscow, Sovetskii khudozhnik Publ., 1980, 264 p. (In Russian)

2. Golomstock I.N. Totalitarnoe iskusstvo [Totalitarian Art]. Moscow, Galart Publ., 1994. 296 p. (In Russian)

3. Tugendkhol'd Ia. A. Germanskoe iskusstvo [German Art]. Ia. A. Tugendkhol'd. Iz istorii zapadnoevropeiskogo, russkogo i sovetskogo iskusstva [From the History of Western European, Russian and Soviet Art]. Moscow, Sovetskii khudozhnik Publ., 1987, pp. 130-137. (In Russian)

4. Gerchuk Iu. Ia. Istoriia grafiki $i$ iskusstva knigi [History of graphics and art of the book]. Moscow, Aspect Press Publ., 2000, 320 p. (In Russian)

5. Tugendkhol'd Ia. A. Graviura i grafika [Engraving and Graphics]. Ia. A. Tugendkhol'd. Iz istorii zapadnoevropeiskogo, russkogo i sovetskogo iskusstva [From the History of Western European, Russian and Soviet Art]. Moscow, Sovetskii khudozhnik Publ., pp. 246-257. (In Russian)

6. Radlov N.E. Po povodu vystavki risunkov i estampov [About the exhibition of drawings and prints]. Apollon [Apollo], 1913, no. 1, pp. 53-55. (In Russian)

7. Efros A.M. V. Favorskii i sovremennaia ksilografiia [Favorsky and modern woodcut]. Russkoe iskusstvo [Russian Art], 1923, issue 1, pp. 37-54. (In Russian)

8. Gollerbakh E. F. Istoriia graviury $i$ litografii v Rossii [History of engraving and lithography in Russia]. Moscow, Petrograd, Gosudarstvennoye izdatel'stvo [State Publ. House], 1923, 240 p. (In Russian)

9. Vipper B.R. Vvedenie $v$ istoricheskoe izuchenie iskusstva [Introduction to the historical study of art], $3^{\text {rd }}$ ed. Moscow, V. Shevchuk Publ., 2010, 368 p. (In Russian)

10. MoMA Highlights: 350 works from the Museum of Modern Art. $2^{\text {nd }}$ ed. New York, The Museum of Modern Art, 2004, 380 p.

Received: 03.10.2017

Accepted: 09.11.2017

Author's information:

Golikova Irina S. — Postgraduate; golart@list.ru 


\section{«Экспрессивная линия» в истории немецкой и русской графики: от прошлого к настоящему}

\section{И. С. Голикова}

Санкт-Петербургская государственная художественно-промышленная академия им. А. Л.Штиглица, Российская Федерация, 191028, Санкт-Петербург, Соляной пер., 13

Для цитирования: Golikova I. S. "Expressive line" in the history of German and Russian graphics: From past to present // Вестник СПбГУ. Искусствоведение. 2018. Т. 8. Вып. 1. С. 52-63. https://doi. org/10.21638/11701/spbu15.2018.104

В статье, поводом к которой стало проведение выставки Ансельма Кифера в Эрмитаже, анализируются параллельные тенденции в немецкой и русской графике XX в. Уточняется роль немецкого экспрессионизма в истории графического искусства. Проводится сравнительный анализ произведений немецких и русских художников 1910-1920-х годов, работавших с печатной графикой. Приводятся выдержки из статей ведущих отечественных художественных критиков данного периода, подтверждающие важность теоретического осмысления понятия «графика» для российского искусствознания. Роль Ансельма Кифера в европейском искусстве последней четверти ХХ в. рассматривается с позиции концептуализации им художественной техники и, в частности, соединения в его работах живописи и печатной графики. Итоговые выводы статьи связаны с обоснованием дальнейшего исследования феномена «параллельной взаимосвязи» русской и немецкой графики.

Ключевые слова: графика, русское искусство, немецкое искусство, искусство ХХ в., Ансельм Кифер.

Контактная информация:

Голикова Ирина Сергеевна - аспирант; golart@list.ru 